\title{
Suggestions for improving patenting
}

\author{
Alexander Bolonkin* \\ Emeritus, USA
}

Submission: August 01, 2018; Published: August 20, 2018

*Corresponding author: Alexander Bolonkin, C\&R, 1310 Avenue R, \#F-6, Brooklyn, NY 11229, USA, Email: abolonkin@gmail.com

Keywords: High cost; Patent Office; Inventions; Creativity; Pumping money; Naive poor individual inventors; Giant brake; Hindrance

\section{Disadvantages of modern patenting in the US}

The main disadvantage is the high cost and duration of the patent. The total expenses of an individual inventor for obtaining a patent are tens of thousands of dollars and several years of exhausting correspondence with the Patent Office (PTO). Even after obtaining a patent, an individual inventor (in most cases, they have a low income) must pay the PTO more than \$3,000 for "maintaining" the patent, otherwise the patent will expire. Any company is more profitable to wait 3.5 years and spend this time developing and testing a sample, rather than spending money on buying or leasing a patent. As a result, about $98 \%$ of inventions are unsold, the inventor remains without a livelihood and permanently loses interest in creativity. At present, the PTO has turned into a powerful pump for pumping money from the naive poor individual inventors, from their patriotic desire to help the country and technical progress. To obtain a patent, the author (Micro-Entity) must pay tens of points for \$70-15000 each. The desire of the PTO to swing money sometimes takes idiotic forms. For example, the PTO requires paying $\$ 70$ for having accepted a provisional application and stored it (without any consideration) in the computer for six months. It should be noted that Google, the Archive and most major libraries accept for free access articles, books, patent applications, music for an unlimited period of time and get the date of admission.

As a result, the PTO has become a giant brake on the way of the technical progress of the United States. The PTO cuts off the bulk of the low income individual inventors. True for large firms, high prices for patenting are not a hindrance. But all firms when they come to work require that engineers and highly qualified employees sign a contract with them, that all their inventions made during the period of work at this firm are transferred to the company for free. This prevents the creation of truly valuable inventions. The most surprising thing is that the US bureaucracy does not care about the interests of the country. Working in NASA as a senior researcher, I made many debates in the field of thermonuclear energy, cosmonautics, nuclear weapons. Being grateful to the United States that America has sheltered me as a political refugee from the USSR, I wanted to register and pass the important US inventions to the US Government without a shiver. The only thing I asked was that the state PTO did not require me to pay for registration of patents, because I was not able to pay them. And what did the NASA management answer me? That they will not register inventions that are not used locally within their local organization. I must apply to private companies (???). And what did the powerful firms that fulfill NASA's orders respond? That I must sign the Agreement that I will never ask them for any reward for using my inventions. Only in this case they will CONSIDER my inventions.

And how did the Government of the USSR do it? It registered all inventions free of charge and took them to itself, issuing only the Author's Certificate to the author. True, the large organization in which the author worked paid the author a miserable reward (1/5 of the monthly salary), and the state promised (in case of mass use of the invention) to pay a reward: a maximum of 20,000 rubles (about $\$ 2,000$ at the exchange rate of the black market), but never it did not pay. I did not want to give important military inventions to the Communists, for I understood the criminal aims of the Government of the USSR. For this I was persecuted in the former Soviet Union. Unfortunately, in the USA I encountered the reverse problem: the state (PTO) creates huge obstacles to technical progress. In this connection, the question arises:

\section{Do we need such a PTO?}

Let's see how writers and musicians solve the problem of intellectual property. They publish their works without any patenting. And if someone starts using them for profit without the permission of the author, then they bring the case to court and demand compensation. Why should not this practice be extended to inventions? You place your application for invention on special free sites (Google, Archive. 
org or PTO) that put the date of placement. The application is formalized according to the Rules of the PTO (history of the invention, detailed description with figures, claims, patent research, etc.). You can add to it the terms of transfer, leasing or purchase. If someone began to use this application without the permission of the author to make a profit, then the author can sue and demand a reward. Such a Registered Application can be submitted by the author to the PTO during the period of validity of the patent (20 years). And only then the PTO can demand a fair payment for the examination of the application and the issuance of the patent. The PTO acts in this case as a primary independent expert. If the author does not agree with the decision of the PTO, he can refer the case to the Arbitration Committee of the PTO or appeal to an ordinary court. The low come inventors over 65 years of age having only SSI can patent for free, but the State receives all rights to the acquisition and pays a small fee. Payments for the "maintenance" of the patent should be canceled.

The State Committee for Inventions is needed, where authors of inventions that are important for the defense, security or technical progress of the country can apply. If the experts recognize the invention as such, then the invention is declared state property or secret, the PTO patent this invention for free, the author is deducted $1 \%$ of the cost of products using this invention, and the Committee (or PTO) $0.5 \%$ for the content of the Committee (PTO).

\section{Brief Summary Suggestions}

a. The application for the invention is drawn up under all Rules of the PTO (history of the invention, detailed description with figures, claims, patent research, etc.). Inventor can add to it the terms of transfer, cost leasing or purchase. The application is posted on an open, widely known website (Google Patent, Archive.org, http:// intellectualarchive.com, PTO or special web side) with free access, which puts the placement date. Give ordinary courts the right to accept statements of claim from the author (or his close relatives in the event of his death), if promulgated non-patented inventions for violation of intellectual property (somebody is using given invention for profit).

b. During the period of validity of the patent (usually 20 years), the author can submit an application to the PTO for examination and issuance of a patent. Only then he pays a fair PTO fee for the examination of the application and the issuance of a patent.

c. The total maximum fee cannot exceed $\$ 100$ for individual inventor. Payments for "maintaining" the patent (Maintenance Fees) should be canceled.

d. The inventor over 65 years of age having only SSI can patent for free.

e. The State Committee for Inventions (or the department in the PTO) is needed, where authors of inventions that are important for the defense, security or technical progress of the country can apply. If the experts recognize the invention as such, then the invention becomes state property or secret, the PTO patent this invention for free. In the future, the author will get $1 \%$ of the cost of products using this invention, and the Committee (or PTO) $0.5 \%$ for the content of the Committee (PTO).

f. All PTO profits should be used to support individual inventors with low income and for inventor over 65 years of age.
Your next submission with Juniper Publishers will reach you the below assets

- Quality Editorial service

- Swift Peer Review

- Reprints availability

- E-prints Service

- Manuscript Podcast for convenient understanding

- Global attainment for your research

- Manuscript accessibility in different formats ( Pdf, E-pub, Full Text, Audio)

- Unceasing customer service

Track the below URL for one-step submission https://juniperpublishers.com/online-submission.php 